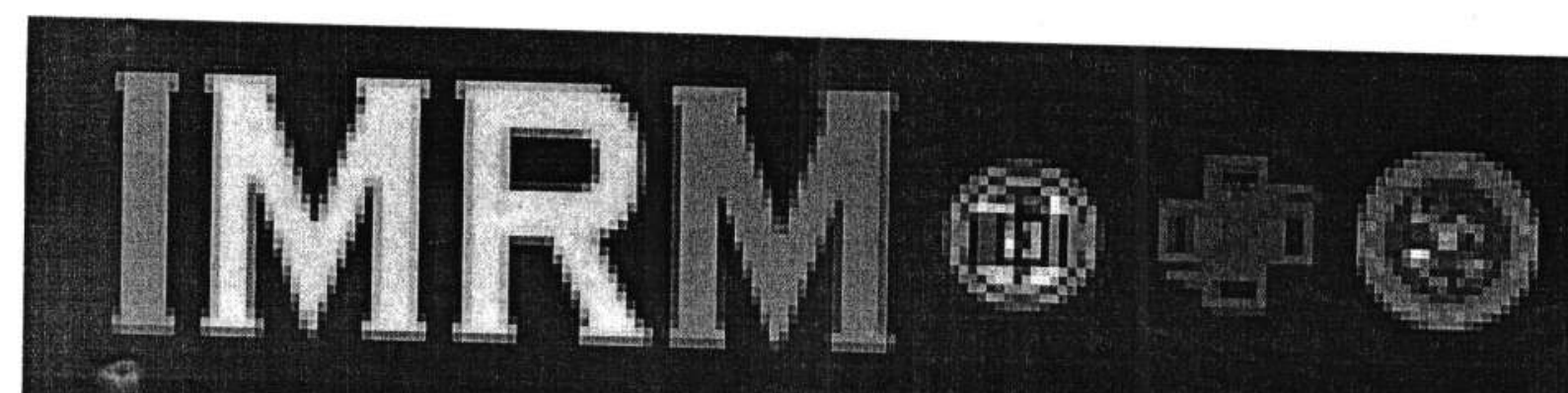

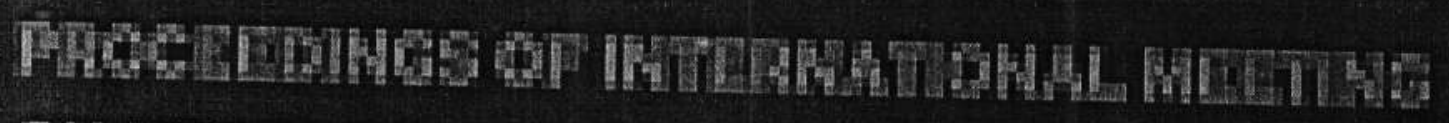

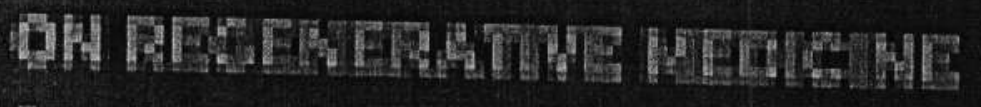

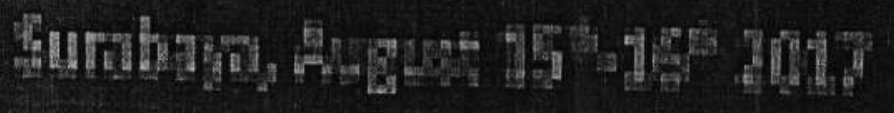

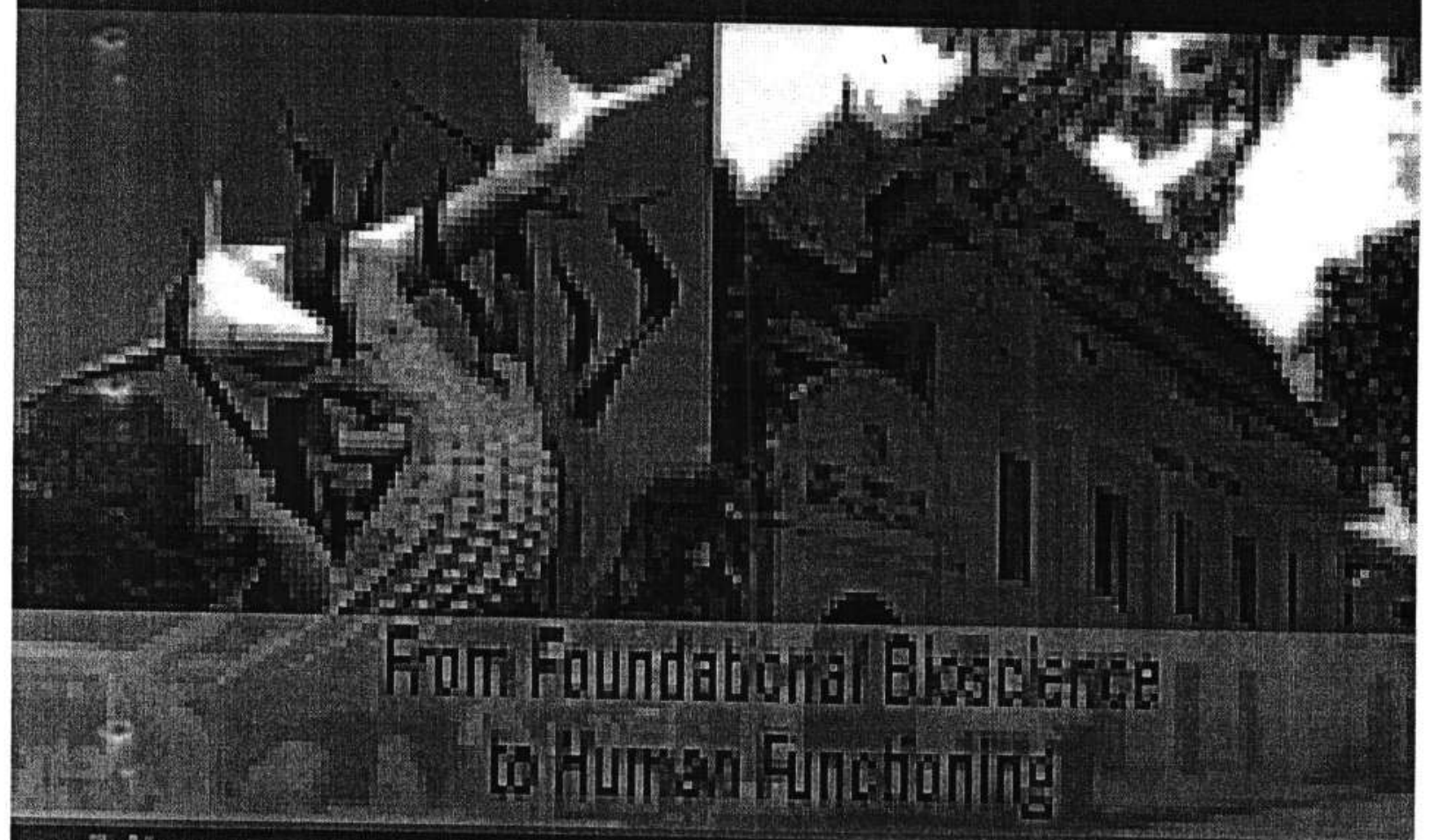

Hetierit

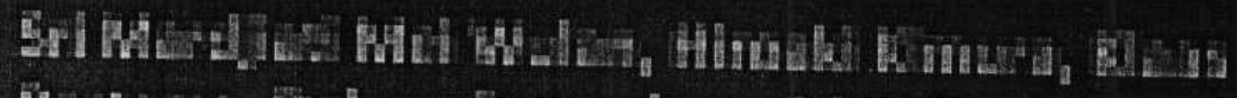

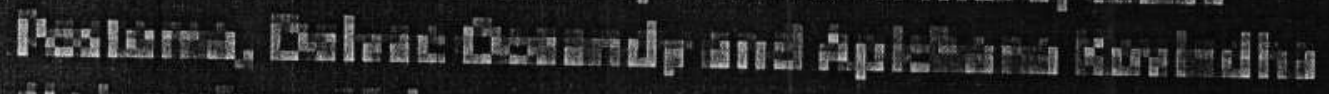

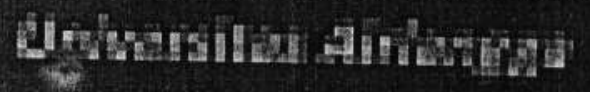

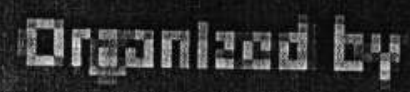

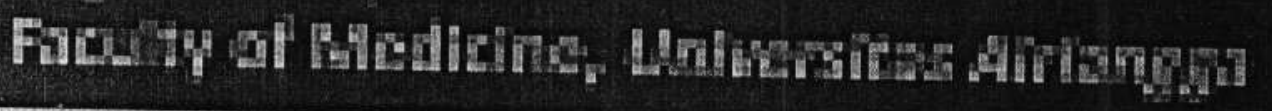


hope that this event will bring (More)

Volumes:

Show 50

Vol. 1 - 978-989-758-334-

Rehabilitation Programs for Total Hip Arthroplasty in Patients with

Enclosed Hip Bilateral: A Case Report

Yuli Indah Kurnia and I Putu Pawana

DOI:10.5220/0007314400050008

Pyruvat Dehydrogenase Deficiency - Physical Medicine and

Rehabilitation Approach: A Case Report

Yuli Indah Kurnia and S.M Mei Wulan

DOI:10.5220/0007314500090012

The Role of EMG Biofeedback and Comprehensive Rehabilitation in

Fitri Azizah Noor and Patricia Maria K

DOI:10.5220/0007314600130017

Rehabilitation Management in Late-Findings of Ankylosing Spondylitis

Patient: A Case Report

Adesti Permanasari and Reni Hendrarati Masduchi

DOI:10.5220/0007314700180022

Rehabilitation of Patients with Foville's Syndrome after the First ICH

Stroke: A Case Report

Bimo Sutomo and Nuniek Nugraheni

DOI:10.5220/0007314800230025

Rehabilitation Management of a Child with Scleroderma: A Case Report P. 26 -

Bayu Putra and Nurul Wardani

DOI:10.5220/0007314900260030

Patient with Multiple Non-contiguous Spondylitis (Spinal) Tuberculosis: P. 31 .

A Case Report

Bayu Putra and Reni Masduchi

DOI:10.5220/0007315000310034

Correlation of ASIA Impairment Scale (AIS) Classification and Pain in

Spinal Cord Injury Patients

DOI:10.5220/0007315100350038

Non-Traumatic Spinal Cord Injury - Tuberculous Spondylitis: A Case

Bona Pardede and Dewi Poerwandari

DOI:10.5220/0007315200390042

Correlation between Parity Status and Urinary Incontinence Among 
Relation of Cognitive and Physical Functional Performance with Urinary P. 46 Incontinence Problems in the Elderly

Dewi Ayub, Rwahita Satyawati and Nuniek Nugraheni

DOI:10.5220/0007315400460048

The Effect of Garlic Extract on Endothelial Progenitor Cells (EPCs)

In Vitro Effect of Lisinopril on Endothelial Progenitor Cell (Epc)

Proliferationts

Yudi Her Oktoviono, Ragil Nur Rosyadi and Djoko Soemantri

DOI: $10.5220 / 0007315600530058$

Intraventricular Transplantation of Autologous Bone Marrow

Clinical Experience

Asra Al Fauzi

DOI:10.5220/0007315700590064

Comparison of the Effects of Resistance Training with and without Vascular Occlusion on Creatine Kinase (CK) and C-Reactive Protein (CRP) 70 David Sugiarto, Hening Laswati, SM Mei Wulan and Hiroaki Kimura DOI:10.5220/0007315800650070

Direct and Indirect Method of Sonographic Measurements of the

DOI:10.5220/0007315900710075

Increasing Muscle Regeneration in Response to Exercise

S.M Mei Wulan

DOI:10.5220/0007316000760080

The Role of Comprehensive Rehabilitation Management in 


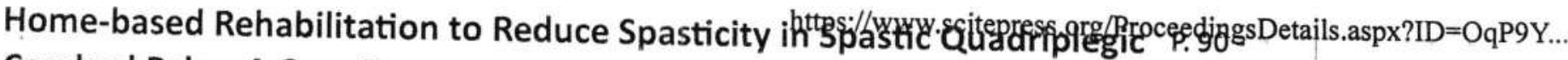
Cerebral Palsy: A Case Report

Mufidha Zulfia and SM Mei Wulan

DOI:10.5220/0007316300900092

Effectiveness of Aerobic Exercise Addition Using a Static Cycle in Improving Cardiorespiratory Fitness and Gait Speed after Sub-Acute Ischemic Stroke

Fifin Indraswari, Hening Laswati and Indrayuni Lukitra W.

DOI:10.5220/0007316400930100

Incentive Spirometer as a Prognostic Factor for Post Cardiac Surgery P. 101 Patients

Bastianus Alfian Juatmadja and Dewi Poerwandari

DOI:10.5220/0007316501010103

Rehabilitation Management of Chronic Inflammatory Demyelinating Polyneuropathy: A Case Report

Sri Panca Lastiani and SM Mei Wulan

DOI:10.5220/0007316601040106

Rehabilitation Management of Intracerebral Hemorrhage with Various

Gadiza Raiznintha P and Ditaruni Asrina U.

DOI:10.5220/0007316701070110

Congenital Scoliosis Caused by Hemivertebrae: A Case Report

Masadah and Nurul Kusuma Wardani

DOI:10.5220/0007316801110114

Anal Pressure Biofeedback Training in a Patient with Diverting

Rehabilitation Outcome of Mixed Transcortical Aphasia and Right Hand P. 125 Function Disturbance in Intracerebral Hemorrhage: A Case Report

DOI:10.5220/0007317101250129 
Benefits of Sport Rehabilitation for Patients with ACL and PCL Tears after P. 135 -

Reconstructive Surgery: A Case Report

Bimo Sutomo and I Putu Alit Pawana

DOI:10.5220/0007317301350139

Rehabilitation Management for Traumatic SCI During Pregnancy: A Case P. 140 Report

Wahyu Sita Wardani and Patricia Maria

DOI:10.5220/0007317401400143

Difficulty of Returning to Work After Traumatic Spinal Cord Injury: A CaseP. 144 Report

Astrina Nur Bahrun and Andriati

DOI:10.5220/0007317501440147

Adolescent Idiopathic Scoliosis Rehabilitation in a Patient with

Tuberculosis-Destroyed Lung: A Case Report

Benni Azhari and I Lukitra Wardhani

DOI:10.5220/0007317601480151

Rehabilitation Intervention in Hypertensive Intracerebral Hemorrhage: A P. 152 . Case Report

Astrina Nur Bahrun and Dewi Poerwandari

DOI:10.5220/0007317701520154

Correlation of Rehabilitation Management Initiation and Length of Stay P. 155 on Traumatic Brain Injury Patients in Dr. Soetomo Hospital Surabaya, 158 Indonesia

Yohan Christian Suisan and Reni Hendrarati Masduchi

DOI:10.5220/0007317801550158

The Role of Comprehensive Rehabilitation Management in Spina Bifida Patient with CTEV: A Case Report

P. 159 -

Yohan Christian Suisan and S.M. Mei Wulan

DOI:10.5220/0007317901590162

Urinary Incontinence Prevalence and Its Relation between Pelvic Floor P. 163 Muscle Strength and Type of Incontinence Urine Based on Incontinence 166 Questions (3IQ) among Elderly Men

Gde Ganjar Oka Narasara , Rwahita Satyawati and Nuniek Nugraheni

DOI:10.5220/0007318001630166

Rehabilitation Challenges of Frequent Implant Failure of the Elbow

Alfin Windarjati Wyoso and I Putu Alit Pawana

DOI:10.5220/0007318101670170

Comprehensive Rehabilitation Program for Cervical Spinal Cord Injury

Caused by Atlantoaxial Dislocation: A Case Series Report 
Rehabilitation Program for Spinal Neurofibromatosis: A Case Report

Meta Novantisari and Damayanti Tinduh

DOI:10.5220/0007318301770180

Rehabilitation of Post Sciatic Nerve Repair with Mesenchymal Stem Cell P. 181 Augmentation: A Case Report

Ikhwan Muhammad and Damayanti Tinduh

DOI:10.5220/0007318401810185

The Effect of Kinesio Taping on Lower Extremity Muscle Power in Adult P. 186 Males

Stela Clara , Julia Windi Gunadi and Yenni Limyati

DOI:10.5220/0007318501860188

The Functional Capacity Difference between Below Elbow Prosthesis

Bodied Subjects

Rahmad, Fatchur Rachman , I Lukitra Wardhani and I Putu Alit P

DOI:10.5220/0007318601890193

Role of Allogeneic NK Cells Treatment in the Early Phase of Apoptosis on P. 194 Poorly Differentiated Retinoblastoma Cells Culture

Ratna Jaya, Susy Fatmariyanti , Endang Retnowati and Ugroseno S

Yudho Bintoro

DOI:10.5220/0007318701940201

The Relationship between Degree of COPD and Malnutrition in Patients P. 202 in The Polyclinic of Meuraxa General Hospital

Husnah

DOI:10.5220/0007318802020205

Affect of Hatha Yoga Exercise in Executive Function of Diabetes Mellitus P. 206 -

Patient

Ernie, Robby Tjandra and Suhartono

DOI:10.5220/0007318902060211

Tooth Mobility as an Impact of Psychological and Psycho-Physical Work P. 212 .

Distress in a Rat Model

Zahreni Hamzah and Elyana Asnar

DOI:10.5220/0007319002120217

Comprehensive Program of Degenerative Scoliosis in Reducing Pain

DOI:10.5220/0007319102180221 
D Kusumawardhana, PM Kurniawati and D Poerwandari

DOI:10.5220/0007319202220226

Functional Mobility and Pain Severity in Older Low Back Pain Patients

Dian Marta Sari , Pavankumar Balachandran, Ahmad Ramdan and

Marina A. Moeliono

DOI:10.5220/0007319302270232

\begin{tabular}{l|l|l|l|} 
Prev & 1 & 2 & Next
\end{tabular}

SCITEPAESS - SCIENCE AND TECHNDLDGY PUELICATIONS, LDA.

\section{RESOURCES}

Proceedings

Papers

Authors

Ontology

\section{CONTACTS}

Science and Technology

Publications, Lda

Avenida de S. Francisco Xavier,

Lote $7 \mathrm{Cv}$. C,

2900-616 Setúbal, Portugal.

Phone: +351265 520185

Fax: +351265 520186

Email: info@scitepress.org

\section{EXTERNAL LINKS}

PRIMORIS

INSTICC

SCITEVENTS

CROSSREF
PROCEEDINGS SUBMITTED FOR INDEXATION BY:

Thomson Reuters

dblp

Ei Compendex

SCOPUS

Semantic Scholar

C 2018 SciTePress, Science and Technology Publications, Lda - All rights reserved. 


\title{
Role of Allogenic NK Cells Treatment in the Early Phase of Apoptosis on Poorly Differentiated Retinoblastoma Cells Culture
}

\author{
Hendrian Dwikoloso Soebagjo', Fitria Kusumastuti', Parma Ratna Jaya', Susy Fatmariyanti ', \\ Endang Retnowati ${ }^{2}$ and Ugroseno S Yudho Bintoro ${ }^{3}$ \\ 'Department/Medical Staff of Ophthalmology, Faculty of Medicine, Airlangga University, Dr. Soetomo Hospital \\ ${ }^{2}$ Department of Clinical Pathology. Faculty of Medicine, Airlangga University, Dr. Soetomo Hospital
${ }^{3}$ Hematology and Medical Oncology Division, Department/Medical Staff of Internal Medicine, Faculty of Medicine, \\ Airlangga University, Dr. Soetomo Hospital \\ hendriands@yahoo.com
}

Keywords: Allogeneic, Apoptosis, Cancer Immunotherapy, NK Cells, Poorly Differentiated Retinoblastoma.

Abstract: Introduction: Retinoblastoma is a retinal malignant tumor because of mutations on chromosome 13q14. This is associated with apoptosis deregulation processes. Both autologous or allogeneic NK cells play their roles in both innate and adaptive immune systems-They can stimulate apoptosis through several mechanisms. Methods: This study determined the role of allogeneic NK cells in retinoblastoma cell apoptosis. Poorly differentiated retinoblastoma tissues were tested with SDS-PAGE. Allogeneic NK cells were isolated from peripheral blood of the healthy family members of patients. There were two culture groups consisting of retinoblastoma cells only as the control and retinoblastoma treated with allogeneic NK cells as the treated group. Each group consisted of 10 well plates. Examinations of the expression of Bcl-2, Caspase-3, and Apoptosis were performed by the flowcytometry method Result: The SDS PAGElelectrophoresis tests showed strong expression of proteins with molecular weights of $14,19,28,35,53$ and 85 kDa The percentage of early-phase-apoptosis is higher than late phase. There were significant correlations $(a<0.05)$ between $\mathrm{Bcl}$ 2 , Caspase-3, and the ratio of both on cell apoptosis. Conclusion: In conclusion, allogeneic NK cells play a

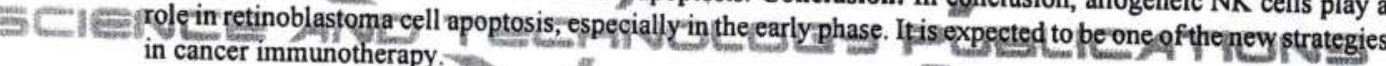

\section{INTRODUCTION}

Retinoblastoma is the most common eye cancer occurring in children. Retinoblastoma is a malignan tumor of the retina that is derived from primitive neuroectodermal tissues. This tumor is caused by mutations on chromosome 13q14. The most common occurrence is diagnosed when children are aged less than 3 years old. The incidence rate reaches approximately $4 \%$ of all malignancies in children. In the United States, retinoblastoma affects 1 in 18,000 children aged less than 5 , and the prevalence reached 250 to 300 cases per year, resulting in a $1 \%$ death rate in all cases. The figures are higher in developing countries and continue to increase annually, making the success of retinoblastoma therapy a constant challenge for developing countries. There were 44 cases from 2010 to 2012 in Dr. Soetomo General Hospital in Surabaya (Bunin \& Orjuela, 2007;
Chantada \& Leal-Leal, 2007; Chintagumpala et al., 2007; Soebagjo et al., 2013; Stewart \& Wild, 2014). Retinoblastoma is a tumor type that is known to be genetically influenced. The mutation of the tumor suppressor gene (RB1) which is located at chromosome $13 \mathrm{q} 14$ is closely related to tumor formation (Leiderman et al., 2007). Due to the genetic mutations occurring in retinoblastoma, proliferation will increase as apoptosis decreases. Homeostasis is achieved when the proliferation rate on the tissue is balanced with apoptosis. When apoptosis deregulation takes place, the number of dividing cells will be higher than the dying cells and in the end, a tumor is formed (Cheng et al., 2013).

The apoptosis process runs through two pathways, which are (1) the extrinsic pathway (cytoplasm) through the activity of the Fas death receptor by activating Fas ligand (FasL) interaction and (2) the intrinsic pathway (mitochondrial) that stimulates 
cytochrome-c release, which depends on $\mathrm{Bcl}-2$ protein regulation (B cell lymphoma) as an antiapoptotic protein and $\mathrm{Bax}$ as a pro-apoptotic protein. Singh et al. (2015) reported that the Bcl-2 is positively correlated to the growth of invasive retinoblastoma cells even though it is not correlated with Bax expression. However, Sitorus et al. (2009) reported that $\mathrm{Bcl}-2$ overexpression would not prevent apoptosis, even though the independent Caspase-3 pathway is the apoptosis main pathway in retinoblastoma (Singh et al., 2015; Sitorus et al., 2009).

One of the cell types which can influence apoptosis occurrence is the Natural Killer (NK) cell. This cell constitutes lymphocytes playing a role in both the innate and adaptive immune systems. These cells can induce apoptosis through several mechanisms. In the last decade, the knowledge of NK cells, both the autologous and allogeneic, has developed and become one of the new strategies in cancer immunotherapy. Davis \& Rizzieri (2015) mention that applying NK cells in atherapy on malignancy showed success and the studies in this field continue to grow rapidly. Eguizabal et al. (2014) state that NK cells play an important role in building immunity against cancer. Soebagjo et al. (2015) report that autologous NK cells play an importantrole in RB cells' aggressiveness through the expression of EZH2, Ki-67, and RB cell apoptosis (Davis \& Rizzieri, 2015; Eguizabal et al., 2014;

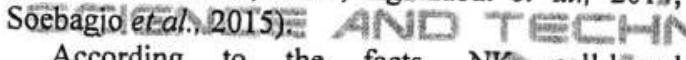
According to the facts, NK cell-based immunotherapy acts as one of the promising alternative therapies. So, investigations into the role of $\mathrm{Bcl}-2$ protein as a regulator and Caspase- 3 as the apoptosis executor on retinoblastoma cells treated with allogeneic NK cell will be the basic treatment especially as an alternative therapy for retinoblastoma cases.

\section{METHODS}

\subsection{Research Subjects}

Poorly differentiated retinoblastoma tumor tissues were collected from the enucleated patients of Dr. Soetomo General Hospital, Faculty of Medicine, University of Airlangga, Indonesia after obtaining informed consent. Fresh tumor tissues were tested using the SDS-PAGE method to determine the molecular weight of proteins. There were two groups consisting of retinoblastoma cells only as the control group and retinoblastoma versus allogeneic NK cells as the treated group. Each group consisted of 10 well plates of cells culture. Expression of $\mathrm{Bcl}-2$, Caspase-3, and Apoptosis was examined with the flowcytometry test.

\subsection{SDS-PAGE}

The SDS-PAGE test is useful to describe the molecular weight of tissue. Basically, proteins in the tissue are extracted in a buffer gel. The gel is then divided into two parts, the stacking gel and separating gel. The stacking gel consisted of $830 \mu \mathrm{L}$ of UGB (upper gel buffer), $534 \mu \mathrm{L}$ of acrylamide (T-acryl), $1950 \mu \mathrm{L}$ of $\mathrm{ddH}_{2} \mathrm{O}, 40 \mu \mathrm{L}$ of ammonium persulfate (APS), and $4 \mu \mathrm{L}$ of tetramethylethylene diamine (TEMED). The separating gel consisted of $2600 \mu \mathrm{L}$ of LGB (lower gel buffer), $4000 \mu \mathrm{L}$ of acrylamide (T-acryl), 3400 $\mu \mathrm{L}$, of $\mathrm{ddH}_{2} \mathrm{O}, 140 \mu \mathrm{L}$ of ammonium persulfate (APS), and $14 \mu \mathrm{L}$ of tetramethylethylene diamine (TEMED). As much as $3 \mu \mathrm{L}$ of tumor tissue was prepared with $\mu \mathrm{LT}$ ris-cl $+15 \mu \mathrm{L}$ of RSB (Reducing Sample Buffer) and then it was separated by electrophoresis gelusing with $100 \mathrm{~V}$ voltage. The gel was then dyed with Coomassie Brilliant Blue R-250 so that the strands of molecules became visible. The molecular weight of each strand could be measured witha standard marke strand. The weight calculation of protein molecules was conducted based on Rf(Retardation factor) strandvalue of feeach Isample.The. migration distance of the polypeptide is a proportional inverse of the logarithin (log) value of the polypeptide molecule weight.

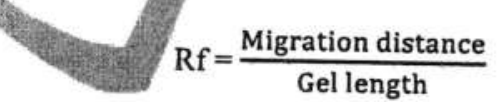

\subsection{Culture of Retinoblastoma Cells}

The retinoblastoma tissue was cleaned 3 times with sterile PBS. It was then finely chopped in serum-free media of type-I collagenase. Finally, it was incubated for 30 minutes at $37^{\circ} \mathrm{C}$. After that, medium plus serum was added and then the tissue was filtered. Next, the tissue was put in a centrifuge for 10 minutes at the speed of $1600 \mathrm{rpm}$. The supernatant was discarded and the pellets were resuspended with medium plus serum. After that, the cell culture was conducted on plates so it became confluent. Multiple passages were conducted until cell lines formed. And then, the confluent culture was divided into two groups. The first was the control 
group which was not treated with allogeneic NK cells and the second was treated with NK cells with the ratio of 1:1 (Soebagjo et al., 2015).

\subsection{Peripheral Blood Collection for Allogeneic NK Cells}

The isolation of peripheral blood mononuclear cells (PBMC) was based on Boyum's method (1968) with some modifications. Isolation of mononuclear cells is often used to analyze the cellular immune responses by reacting antibody with mononuclear cell-surface antigens (Bøyum, 1968; Rantam, 2003).

The peripheral blood collection for NK cell isolation was performed on healthy biological family members of the retinoblastoma patients. The blood samples were stored in a $\mathrm{K}_{3}$ EDTA vacuum tube for PBMC isolation. In addition, the collection of NK cells can also be conducted through stem cell growth by adding GM-CSF growth factor to the NK cel culture process (Bøyum, 1968).

\subsection{Examination of the Number of NK Cells (CD3 $-\mathrm{CD}^{-}{ }^{+} / \mathrm{CD} 16{ }^{+}$}

The NK cell examination was performed using flowcytometry by means of $\mathrm{BD}$ FACS CaliburTM reagents of BD TriTESTTM CD 3 Fluorescein isothiocyanate (FITC)/CD16 ${ }^{+} \mathrm{CD} 56$ phycoerythrin (PE)/CD45 and perjdinin-chlorophyll protein (PerCP), which are the pigment reagents of immunofluorescein to determine the number of NK cells (CD3-CD56 ${ }^{+} / \mathrm{CD}^{-} 6^{+}$(Hu et al., 2012).

The NK cells expressing CD3; $\mathrm{CD}^{+} 6^{+}$, and $\mathrm{CD}^{+} 6^{+}$would experience fluorescence in accordance with the area and then gating was performed on NK cells in the expression areas of $\mathrm{CD}^{+} 6^{+} / \mathrm{CD}^{2} 6^{+}$and areas without the expression of $\mathrm{CD} 3$ (CD3-). The number of NK cells (cells/ $\mu \mathrm{L}$ ) was obtained by calculating the ratio of cell event expressing CD3. $\mathrm{CD} 56^{+} / \mathrm{CD} 16^{+}$with fluorescent bead event; the number was previously discovered on the BD TruCOUNT tube (Hu et al., 2012).

\subsection{Examination of Cells Expressing Bcl-2, Caspase-3, and Apoptotic Cells}

The examination of cells expressing Bcl-2, Caspase3 , and apoptotic cells was conducted using flowcytometry by means of BD FACS Calibur ${ }^{\mathrm{TM}}$, reagents of the primary antibody of Anti-Bcl-2 (100) FITC and FITC Active Caspase-3 Apoptosis, and FITC Annexin V Apoptosis Detection Kit II
Cat. 556570 , fixation reagents of $\mathrm{BD}$ Cytofix/Cytoperm ${ }^{\mathrm{TM}}$, permeabilization reagents of BD FACS Permeabilizing Solution 2, washer reagents of $B D$ Perm/Wash ${ }^{\mathrm{TM}}$ buffer, and lysis reagents of $B D F A C S$ Lysing Solution. Staining with Annexin V is typically used in conjunction with a vital dye such as propidium iodide (PI) for identification of early and late apoptotic cells. Meanwhile, the number of cells that expressed $\mathrm{Bcl}-2$ and Caspase-3 (cells/ $\mu \mathrm{L}$ ) was obtained by calculating the ratio of cell-event expressing antibodies with fluorescent bead events that was previously discovered on the BD TruCOUNT tube.

\subsection{Statistical Analysis}

All of the results were collected in specific data collection sheets, grouped and presented in tabular forms 'and diagrams, and then analyzed by using SPSS 15.0 so as to analyze the amount of $\mathrm{Bcl}-2$ and Caspase- 3 and apoptosis between two groups using a T-Test and the Mann-Whitney Test. The correlation analysis-between the variables was conducted by Spearmann's Rank Correlation Test. The p value was $<0.05$ which statisticallynindicated a significance.

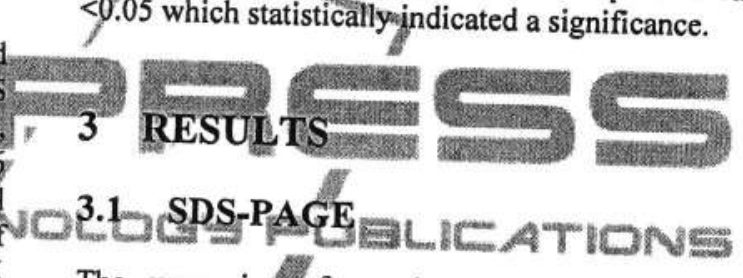

The expression of protein fractions from poorly differentiated retinoblastoma samples was suggested from some arising proteins with the molecular weight range of $14-85 \mathrm{kDa}$. The SDS-PAGE electrophoresis test showed a strong expression of the protein with the molecular weights of $14,19,26,35,53$ and 85 $\mathrm{kDa}$ (Figure 1). Some protein fraction expressions are in accordance with the theory on the possibility of some proteins with molecular weights contained in the poorly differentiated retinoblastoma samples.

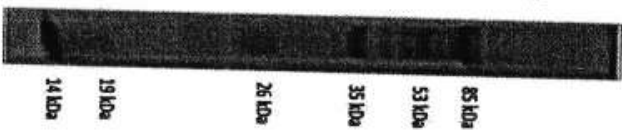

Figure 1: Profile of retinoblastoma protein with SDS-PAGE test. Protein expression in retinoblastoma samples including proteins with molecular weights of $14,19,26,35$,
40,53 , and $85 \mathrm{kDa}$.

The characterization overview of the culture of retinoblastoma cells showed cell growth between the control group and the treated group during the three 
days' incubation period. The control group showed retinoblastoma cell growth shown by the grouping and confluent cell layers (Figure 2B).

In the treated group, there was less growth of retinoblastoma cells and the culture showed the formation of remnant sand of NK cells with the dead (apoptotic) cells surrounding between (Figure 2D). the control group the expression did not occur $(0.10 \pm 0.10 \%)$. Caspase- 3 expression in the treated group was $90.27 \pm 1.70 \%$. It was higher compared with the control group $(70.03 \pm 3.63 \%)$. The percentage of apoptotic cells in the treated group was $27.69 \% \pm 2.36$. It was lower compared with the control group $(37.72 \% \pm 2: 01)$.
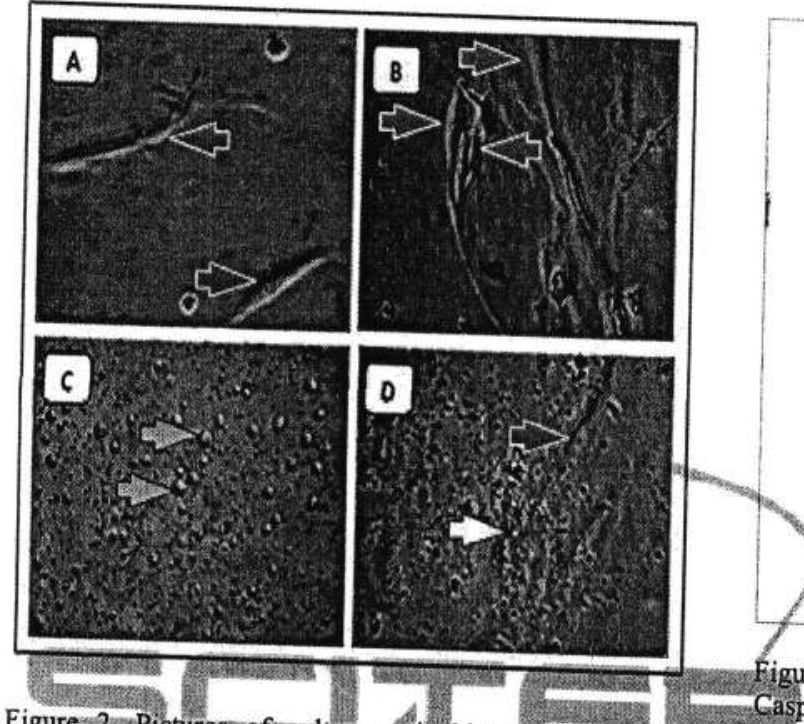

Figure 2. Pictures of culture retinoblastoma cells: A) Control group: culture of retinoblastoma cells (pre3 days i B Control group: culture of retinoblastoma cells 3 days poste seeding, C) A reated group =culture of retinoblastoma cells with NK cells (pre seeding); D) Treated group: culture of retinoblastoma cells with NK cells 3 days post seeding; (Yellow arrow: NK cells; White arrow: overview of remnants of cell group undergoing apoptosis; Green arrow: intact retinoblastoma cells) (magnification:
$400 \mathrm{x}$ ).

\section{DISCUSSIONS}

\subsection{Expression Percentage and Ratio of Bcl-2, Caspase-3, and Apoptosis on Retinoblastoma Cells Culture}

The results showed the percentage of apoptotic cells, necrotic cells and living cells as well as the expression of antibodies Bcl-2 and Caspase-3 and the expression ratio of $\mathrm{Bcl}-2$ and Caspase- 3 in the control group and treated group. The expression was calculated based on the mean percentage $( \pm S D)$ of positive cells expressing antibodies through the flowcytometry test.

The mean percentage of the cells that expressed $\mathrm{Bcl}-2$ in the treated group was $0.10 \pm 0.10 \%$, while in

\subsection{The Effectrof NK Cell Treatment on the Tótal Expression of $\mathrm{Bcl}$ - 2, Caspase-3, and Cultured Retinoblastoma Cell Apoptosis}

The effect of NK cell treatment on retinoblastoma cell apoptosis was calculated by the pigmentation of Annexin V/PI and flowcytometry analysis (Figure 4). The number of cells undergoing apoptosis was calculated based on the increasing concentration of apoptotic cells at early or late phases. Flowcytometry worksheets showed four areas to evaluate cell condition. Living cells can be observed on the lower left, early phase of apoptotic cells on the lower right, late phase on the upper right, and necrotic cells on the upper left side. As the marker of the apoptotic cells, it was strong positively with Annexin V and negative
with PI.

The number of early apoptosis in the treated group was $20.17 \% \pm 1.81$, slightly higher than the control group $(19.53 \pm 2.36)$. In contrast, the percentage of the late phase apoptosis in the treated group of $7.51 \pm 6.01$ is significantly lower than the control group (18.2 \pm 1.09$)$. 
The ratio of Bcl-2 and Caspase- 3 was calculated to describe the difference between the expression of each parameter. There was no difference between the two groups (treated group was $0.11 \pm 0.11 \%$ versus control group of $0.00 \pm 0.00 \%$ ).

The different test result analysis of all variables using the Mann-Whitney test and Independent T. test between the treated group and control showed a significant result among them. In addition, Spearmann's Rank correlation test between variables and apoptosis showed a significant result

Table 1: Different Test Result Analysis Control and Treatment in Phase Apoptosis.

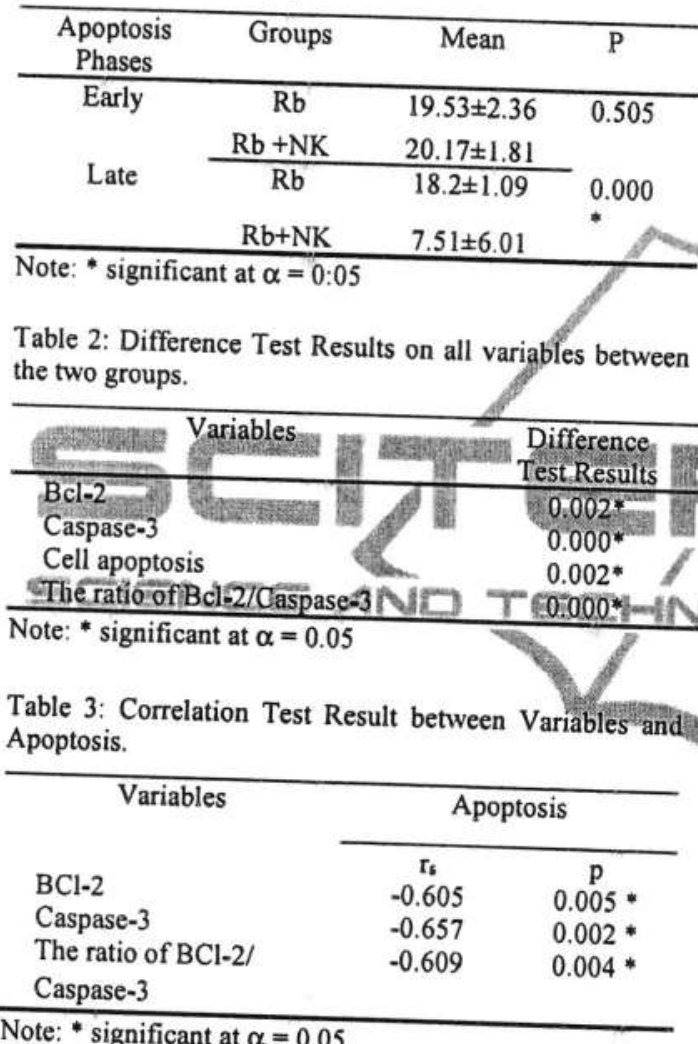

Note: * significant at $\alpha=0.05$
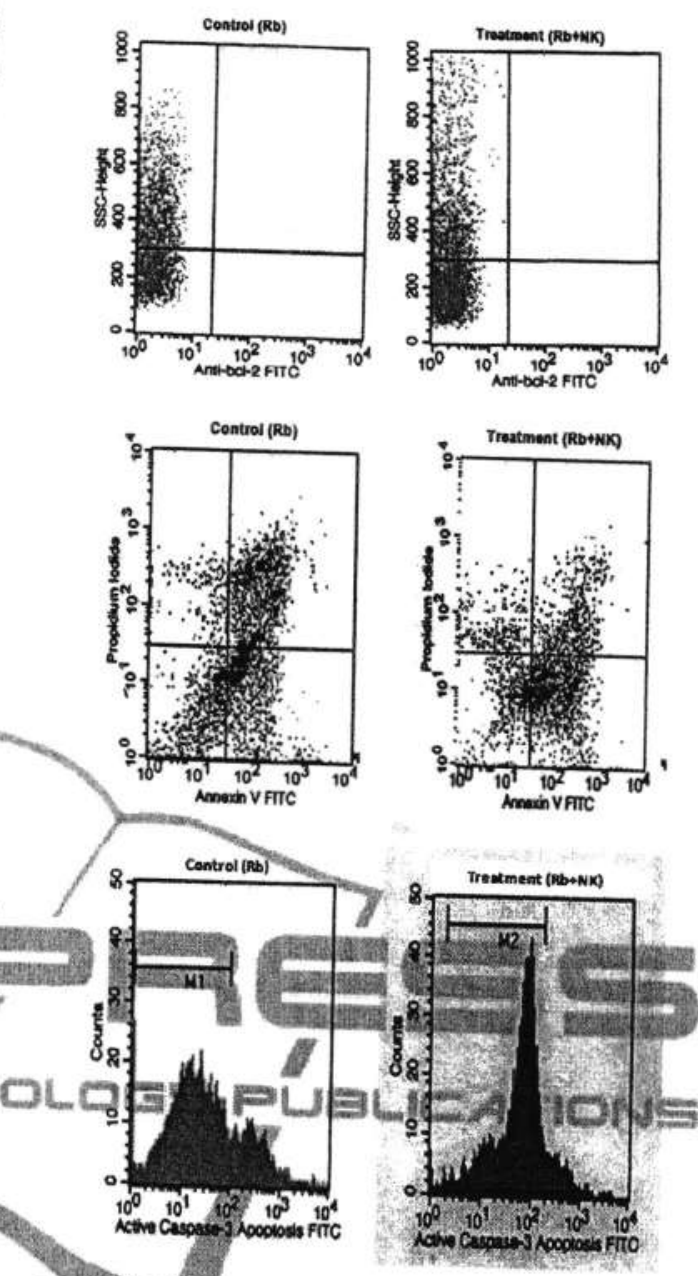

Figure 4: Overview of flowcytometry on expression of Bcl2, Caspase-3 and Apoptosis between the two groups.

A typical figure of retinoblastoma cell given NK cells is seen as the formation of remnant cells and NK cells surrounding cells that have an apoptotic process. Soebagjo et al. (2015) reported that NK cells have the ability to induce retinoblastoma cells thus inhibiting tumor cell growth and finally cause cell death. Therefore, NK cells are found surrounding the dead cells. In contrast, retinoblastoma cells grew normally in the control group (Soebagjo et al., 2015).

The SDS-PAGE electrophoresis test on poorly differentiated retinoblastoma samples shows strong expression of proteins with the molecular weights of $14,19,26,35,53$ and $85 \mathrm{kDa}$. The expressions show that there are proteins corresponding to $\mathrm{Bcl}-2$ and Caspase-3 that play a role in retinoblastoma formation. 
Raghupathi et al. (2003) measured the molecular weight of Bcl-2 $(26 \mathrm{kDa})$ and $\mathrm{Bax}(21 \mathrm{kDa})$ by using immunoblot on HeLa cortex and hippocampus cells. In the cardiomyocytes, two types of $\mathrm{Bcl}-2$ expressions with different molecular weights were obtained (26 and $32 \mathrm{kDa}$ ) (Raghupathi et al., 2003; Cook et al., 1999).

Caspase-3 with a molecular weight of $35 \mathrm{kDa}$ is a form of fraction activated by $\mathrm{T}$ cells and is found in the cell cytoplasm. In addition, $35 \mathrm{kDa}$ molecular weight is similar to the molecular weight of procaspase-7 and pro-caspase-9 (Paulse et al., 2008; Dean et al., 2002; Kadirvel et al., 2010).

The process of cell death or apoptosis is commonly used as the selective parameter of a proposed anti-cancer source. Apoptosis induction was indicated by an increase in the percentage of cells undergoing apoptosis. The average of early apoptosis in the treated group was higher compared with the control group, while late apoptosis in the treated group was lower compared with the control group. So, NK cells play a role in early phase apoptosis. Cheng et al. (2013) mentioned the role of NK cells especially in the early stage of a good immune system both on innate and adaptive immune systems. Poggi et al. (2005) mentioned that the apoptosis trigger induced by $\mathrm{NK}$ cells will bind phosphatidylserine exposed on the surface of apoptotic cells and is marked by Annexin $V$ in the early apoptosis phase. In contrast, in late-phase apoptosis, the death rate of both retinoblästoma cells and NK cells cannot be distinguished Poggi et al. (2005) mentioned that the role of NK cells is effective on 24-hour incubation and it will reach the peakat 48 hours of incubation together inside tumor cells (coculture)(Cheng et al., 2013; Poggi et al., 2005).

The flowcytometry analysis showed that $\mathrm{Bcl}-2$ is relatively insignificant in the apoptosis process. However, caspase- 3 showed significant cell expression but apoptotic cells were lower compared with the control group. The correlation of $\mathrm{Bcl}$ 2/Caspase-3 showed that $\mathrm{Bcl}-2$ yielded less expression when compared with Caspase3. Nevertheless, Caspase- 3 turned out to be inversely proportional to the occurring cell apoptosis. This shows the apoptotic signaling process that occurred in allogeneic NK cells in retinoblastoma cells. In general, the process of NK cell apoptosis goes through two pathways, which are (1) the intrinsic pathway which goes through the NKG2D ligand or (2) the extrinsic pathway which goes through the TNF ligand/FasL (Dranoff, 2004; Krzewki \& Coligan, 2012).
The NK cells will induce tumor cells through Killer Activation Receptors (KARs), i.e. the NKG2D ligand when the KIR inhibitory signal is hampered because the tumor cells are inhibited by the expression of MHC class 1 which cause cytotoxic granules (perforin and granzyme) to not be excreted. The cytotoxic granules will be excreted if NK cell receptors, FcYRIII (CD16) bind IgG tumor cells. Excreted perforin will open pores as the entrance of granzyme protein to mediate apoptosis (Dranoff, 2014; Abe et al., 2008).

There are 5 types of granzyme known to exist in humans. These are granzyme A, B, H, K, and $M$. The difference of the types lies in the structure of the serine protease substrate (Grossman et al., 2004). Hochegger et al. (2004) mention that the class of polymorphonuclear cells (PMN) excrete perforin and 2 types of granzyme which are granzyme $A$ and $B$ which contribute to the process of cytotoxic cells. Granzyme A induces cell death through the DNA characteristic of single chain cells and do not activate caspase cascade (Bots \& Medema, 2006).

In NK cells, granzyme B plays a role. Granzyme B is capable of directly inducing apoptosis (bypass) via - Caspase-3. This is consistent with the results of research and can occur because $\mathrm{Bcl}-2$ is not sufficient to affect the apoptosis process. Overexpression of $\mathrm{Bcl}-2$ in retinoblastoma itself is noted to not necessarily hinder the apoptosis process. The reason why Bcl-2 is not functional is

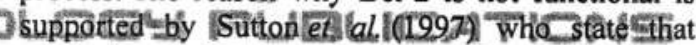
constraints on BCF-2 will have an effect on increasing the ratio of the target and increase granzyme $B$. Granzyme B itself activates Bid pro-apoptotic proteins, along with Bax, which translocates to the mitochondria and affects the membrane permeability to release cytochrome-c after forming apoptosome by the Caspase cascade (Sitorus et al., 2009; Bots \& Medema, 2006; Sutton et al., 1997; Pinkoski et al., 2001).

In addition, Pinkoski et al. (2001) mentioned that in a direct path from granzyme B to caspase-3, apoptosis via the mitochondria can also occur via Smac/Diablo proteins that mediate apoptosis of granzyme B contributing to cell destruction by binding with XIAP. In addition, the release of Smac/Diablo in mitochondria will inhibit the Bcl-2 (Pinkoski et al., 2001; Verhagen et al., 2000; Adrain et al., 2001). 


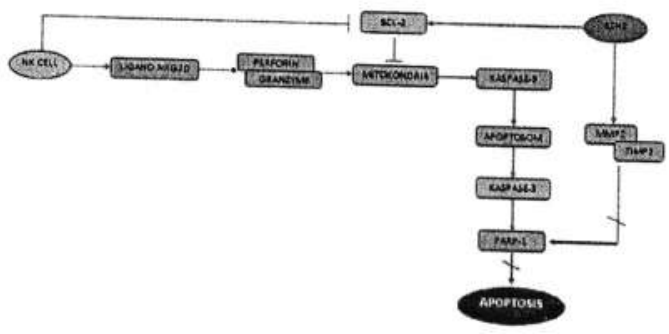

Figure 5: A schematic possible pathway of the induction of NK Cells on apoptosis in Retinoblastoma Cells.

The test results indicate that the ratio of the expression of Caspase-3 increased, reversely proportional to cell apoptosis. Sitorus et al. (2009) stated that there is a possibility that apoptosis occurs through Caspase-3 -dependent or independent pathways. Apoptotic signals that have come to the Caspase-3 effector are possibly hindered by DNA enzyme of repair poly(ADP-ribose) polymerase-1 (PARP-1). Active Caspase-3 protein will divide various substrates, including PARP-1 which is the mitotic apparatus core, lamina nucleus, and also actin and endonucleases. PARP-1 plays an important role in DNA repair processes by participating in the initiation of base excision repair (BER), nucleotide excision-repair, and base repair with single-stranded DNA ligase III mediation, as well as controlling $60-$ $70 \%$ of cell metabolism, cell cycle and cell transcription. Celldeath signals of Caspase-3 towards PARP-1 cleave and the PARP-1 fragments owill activate cell apoptosis. The cleavage process of PARP-1 is conducted by cytokine of Matrix Metalloproteinase-2 (MMP-2). However, the cleavage process by MMP-2 is inhibited by Enhancer Zeste Homolog-2 (EZH2) that represses micro RNA 21 promoters and inhibits MMP-2 through TIMP-2 inhibitors. Barriers on PARP-1 will result in the increased expression of Caspase-3 and in opposite proportion to cell apoptosis (Lazebnik et al., 1994; Nicolescu et al., 2009).

\section{CONCLUSIONS}

It is concluded that the provision of allogeneic NK cells play a significant role in the apoptosis process of poorly differentiated retinoblastoma cells, especially at the early phase through the intrinsic pathway.

\section{REFERENCES}

Abe, H., Akiyama S. \& Okamoto, M.,2008, 'Clinical Cancer Immunotherapy: Molecular Targeting Immunotherapy',J Integ Med, I(1),38-46.

Adrain, C, Creagh E.M. \&Martin, S.J., 2001, 'ApoptosisAssociated Release of Smac/DIABLO From Mitochondria Requires Active Caspases and Is Blocked by Bcl-2', EMBOJ,20(23), 6627-6636.

Bots, M. \& Medema, J.P., 2006, 'Granzymes at A Glance', Journal of Cell Science, 119, 5011-5014.

Bøyum, A., 1968, 'Isolation of mononuclear cells and granulocytes from human blood' (Paper IV), Scand. J. Clin. Lab. Invest, 21 Suppl.,97, 77-89.

Bunin,G.R. \&Orjuela, M., 2007, Clinical Ophthalmic Oncology,Philadelphia: Saunders Elsevier, 410-414.

Chantada,G.L. \&Leal-Leal, 2007,Geographic and Environmental Factors in Singh (Ed.). Clinical Ophthalmic Oncology,Philadelphia: Saunders Elsevier. 2007. pp.417-420.

Cheng', M., Chen, Y., Xiao, W., Sun,R. \&Tian, Z., 2013,'NK Cell-Based Immunotherapy for Malignant Diseases',Cellular \&Molecular Immunology, 10, 230. 252.

Chintagumpala, M., Chevez-Barrios, P., Paysse, E.A, Plon, S.E.\&Hurwitz R, 2007,'Retinoblastoma: Review of Current Management', The Oncologist, 10:12, 12371246.

Cook, S.A, Sugden, P.H \& Clerk, A,1999, Regulation of Bcl-2 Family Proteins During Development andin Response To Oxidativel Stressin Cardiac Myocytes: Association with Changesin Mitochondrial Membrane Potential',Circulation Research, 85,940-949

Davis, C.T. \&Rizzieri,D, 12015 , Immunotherapeutic Applications of NK Cells', Pharmaceuticals, 8, 250256.

Dean, A.L., Wu, Y., Huang, Z., Matsushita, K., Plesnila, N., Augustinack, J.C,et al.. 2002, "Caspase Activation and Neuroprotectionin Caspase-3-Deficient Mice AfterIn Vivo Cerebral Ischemia and In Vitro Oxygen Glucose Deprivation', PNAS, 23(99),15188-15193.

Dranoff, G., 2004, 'Cytokinesin Cancer Pathogenesis and Cancer Therapy', Nat Rev Cancer, 4(1), 11-22

Eguizabal, C., Zenarruzabeitia, O., Monge, J., Santos, S., Vesga, M.A., Maruri, N.,et al., 2014, 'Natural Killer Cells for Cancer Immunotherapy: Pluripotent Stem Cells-Derived NK Cells As An Immunotherapeutic Perspective', Frontiersin Immunology, 5, 1-10.

Grossman, W.J., Verbsky, J.W., Tollefsen, B.L., Kemper, C., Atkinson, J.P. \& Ley, T.J.. 2004, 'Differential Expression of Granzymes A and Bin Human Cytotoxic Lymphocyte Subsets and T Regulatory Cells', Blood, 104 (9), 2840-2848.

Hochegger, K., Eller, P. \& Rosenkranz, A.R., 2004, 'Granzyme A: An Additional Weapon of Human Polymorphonuclear Neutrophils (PMNs)in Innate Immunity?', Blood, 103 (3), 1176.

Hu, P., Hegde, M.\&Lennon, P.A., 2012, Modern Clinical Molecular Techniques, New York,Springer. 
Kadirvel, R., Ding, Y.H., Dai, D.,Lewis, D.A. \& Kallmes, D.F., 2010,'Intrinsic PathwayMediated Apoptosis In Neuroradiol, $31,165-169$. Rabbits', AJNR Am J Neuroradiol, 31, 165- 169.

Krzewki, K. \& Coligan, J.E., 2012, 'Human NK Cell Lytic Granules and Regulation of Their Exocytosis, Review Article',Front Immunol., 3(335), 1-16.

Lazebnik, Y.A., Kaufmann, S.H., Desnoyers, S., Poirier, G.G. \& Earnshaw, W.C., 1994, 'Cleavage of Poly (ADP-Ribose) Polymerase by a Proteinase with Properties like ICE', Nature, 371, 346-347.

Leiderman, Y.L.,et al., 2007, 'Molecular Genetics of RBIThe Retinoblastoma Gene',Seminarsin Ophtalmology,
22,247-254.

Nicolescu, A.C., Holt, A., Kandasamy, A.D., Pacher, P \&Schulz, R., 2009, 'Inhibition of Matrix Metalloproteinase-2 by PARP Inhibitors', Biochem Biophys Res Commun., 387, 646-650

Paulsen, M., Ussat, S., Jakob, M.,Scherer, G., Lepenies, I. \& Schutze, S.,et al., 2008, 'Interaction with XIAP Prevents Full Caspase-3/-7 Activationin Proliferating Human T Lymphocytes', Eur J Immunol., 38, 1979-
1987.

Pinkoski,M.J., Waterhouse, N.J., Heibein, J.A., Wolf, B.B., Kuwana, T., Goldstein, J.C., Newmeyer, D.D., Bleackley, R.C. \& Green, D.R., 2001, 'Granzyme Bmediated Apoptosis Proceeds Predominantly through a Bcl-2-Inhibitable Mitochondrial Pathway',J Biol Chem. 13, 276 (15),12060-7.

Poggi, A. Massaro, A Negrini, S., Contin M.R., 2005, 'Tumor-Induced Apoptosis of Human II2-Activated NK Cells:Role of 'Natural Cytotoxicity Receptors',J Immunol., 174, 2653-2660.

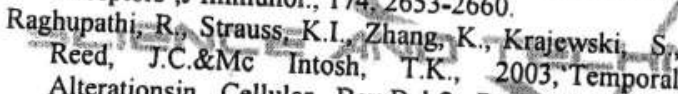
Alterationsin Cellular Bax:Bcl-2 Ratio Following Cenjuryin The Rat',J Neurotrauma

Rantam, F.A., 2003, Metode Imunologi, Airlangga
University Press, Surabaya.

Singh, Purs, Surabaya.

Bakhshi, S., et N.,Saini, N., Sen, S., Sharma, A. Bax Bax and Anti-Apoptotic Bcl-2 Proteinsin Human

Sitorus, R.S., Gumay, S. \& Vphthalmol.,43(3),259-67. Apoptotic Paradoxin Retan Der Valk, P., 2009, 'The Sci.,1171:77-86.

Soebagjo,H.D., Prastyani,R., Sujuti,H Sumitro,S.B, 2013, 'Profile of Retinobrawati, D, \& Java, Java, Indonesia', World Journal of Medicine and Medical Science Research,3, 051-056.

Soebagjo, H.D., Fatmariyanti,S. \&Lutfi,D., 2015, Effectiveness of Natural Killer (NK) Cellsin Periphera Blood Stem Cell Towards Expression of EZH2, Ki-67 and Apoptosisin Retinoblastoma (RB) Cells Culture',Medicine Science, 04, 1-17.

Stewart,B.W. \&Wild,C.P., 2014, 'Global Epidemiology of Cancer', Jones \&Bartlett Learning LLC, 3,45.

Sutton, V.R., Vaux, D.L. \&Trapani, J.A., 1997, 'Bcl-2

Prevents Apoptosis Induced by Perforin and Granzyme
B, But Not That Mediated by Whole Cytotoxic . Immunol., 158, 5783-5790.

Connolly. Lerhagen, P.G., Pakusch, M., Silke, J, of DIABL Apoptosis by a Mammalian Protein That Promotes Apoptosis by Binding to and Antagonizing IAP
Proteins',Cell, 102(1), 43-5 